\title{
Geochemistry of Some Carbonate Secreting Marine Living Organisms From North West Arabian Gulf
}

\author{
Solak A. Darmoian \\ Abdul-Mutalib H. Al-Marsoumi \\ Department of Geology - College of Science \\ Basrah University
}

(Received February 20, 2002 ; Accepted June 18, 2002)

\begin{abstract}
A total, 15 chemical variables have been determined from 29 samples representing skeletons of some carbonate secreting organisms from the north west Arabian Gulf. The analysis are reported as percent $\mathrm{SiO}_{2}, \mathrm{Al}_{2} \mathrm{O}_{3}, \mathrm{FeO}, \mathrm{CaO}, \mathrm{MgO}, \mathrm{CO}_{2}, \mathrm{P}_{2} \mathrm{O}_{5}, \mathrm{Na}_{2} \mathrm{O}, \mathrm{K}_{2} \mathrm{O}$, $\mathrm{SO}_{3}, \mathrm{TiO}_{2}, \mathrm{MnO}, \mathrm{NiO}, \mathrm{PbO}$ and $\mathrm{SrO}$.

Mineralogical analysis revealed the presence of Aragonite, Low Magnesium Calcite (LMC) and High Magnesium Calcite HMC) as dominant minerals, and quartz. Dolomite and feld- spar as traces. Chemical analyses indicates thiat the main differences in the constituents of the studied skeletons are controlled by the water chemistry, mineralogy, growth rate, calcification processes and the nature of the constituents.

\section{جيوكيميائية بعض الكائنات الحية الفارزة للكاربينيت من شمال غزب الخليتج المعبيي}

اللخلص

ما مجموعة 15 متخير تم تعينهافي 29 نموذج تمنل هياكل بعض الكائنات الحية الفارزة للكاربونايت

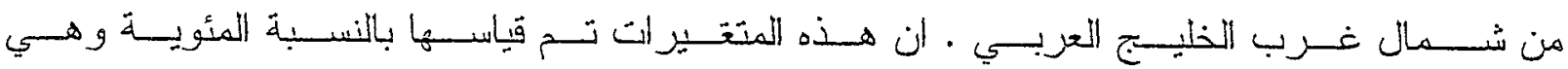
$\mathrm{TiO}_{2} \mathrm{MnO}$ ، $\mathrm{SO}_{3} \quad$ ، $\mathrm{K}_{2} \mathrm{O}$ ، $\mathrm{Na}_{2} \mathrm{O}$ ، $\mathrm{P}_{2} \mathrm{O}_{5} 6 \mathrm{CO}_{2}$ ، $\mathrm{MgO}$ ، $\mathrm{CaO}$ ، FeO $6 \mathrm{Al}_{2} \mathrm{O}_{3}$ ، $\mathrm{SiO}_{2}$ . $\mathrm{SrO}$ ، $\mathrm{PbO}$ ، $\mathrm{NiO}$.

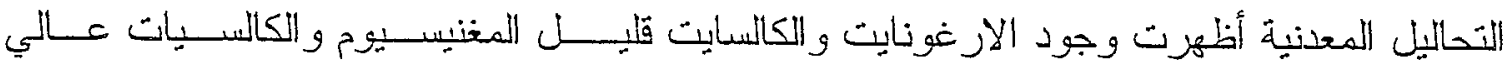

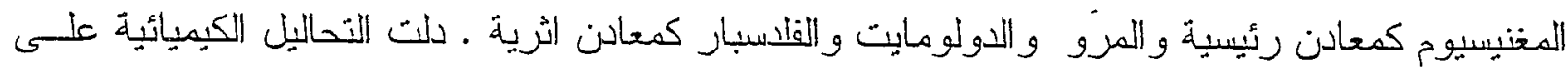

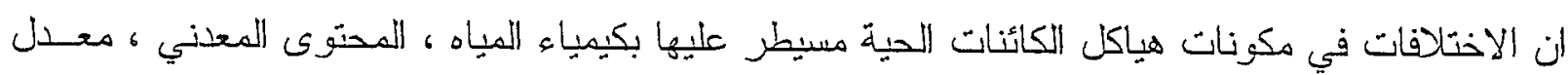

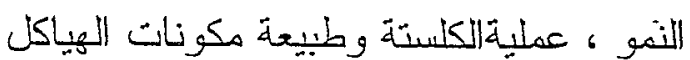




\section{INTRODUCTION}

The Arabian Gulf is a natural isolated arm of Indian Ocean (a marginal sea) with an average depth of $35 \mathrm{~m}$ and maximum of 100 near the straight of Hurmuz Figure (1). According to Hartman et al., (1971), the regional currents attain velocities about 50 $\mathrm{cm} / \mathrm{sec}$ influencing sediments, including skeletal particles, in all parts of the basin. The wind driven currents remain the most influenced mechanisms of sediments transported along the shallow Arabian Gulf part.

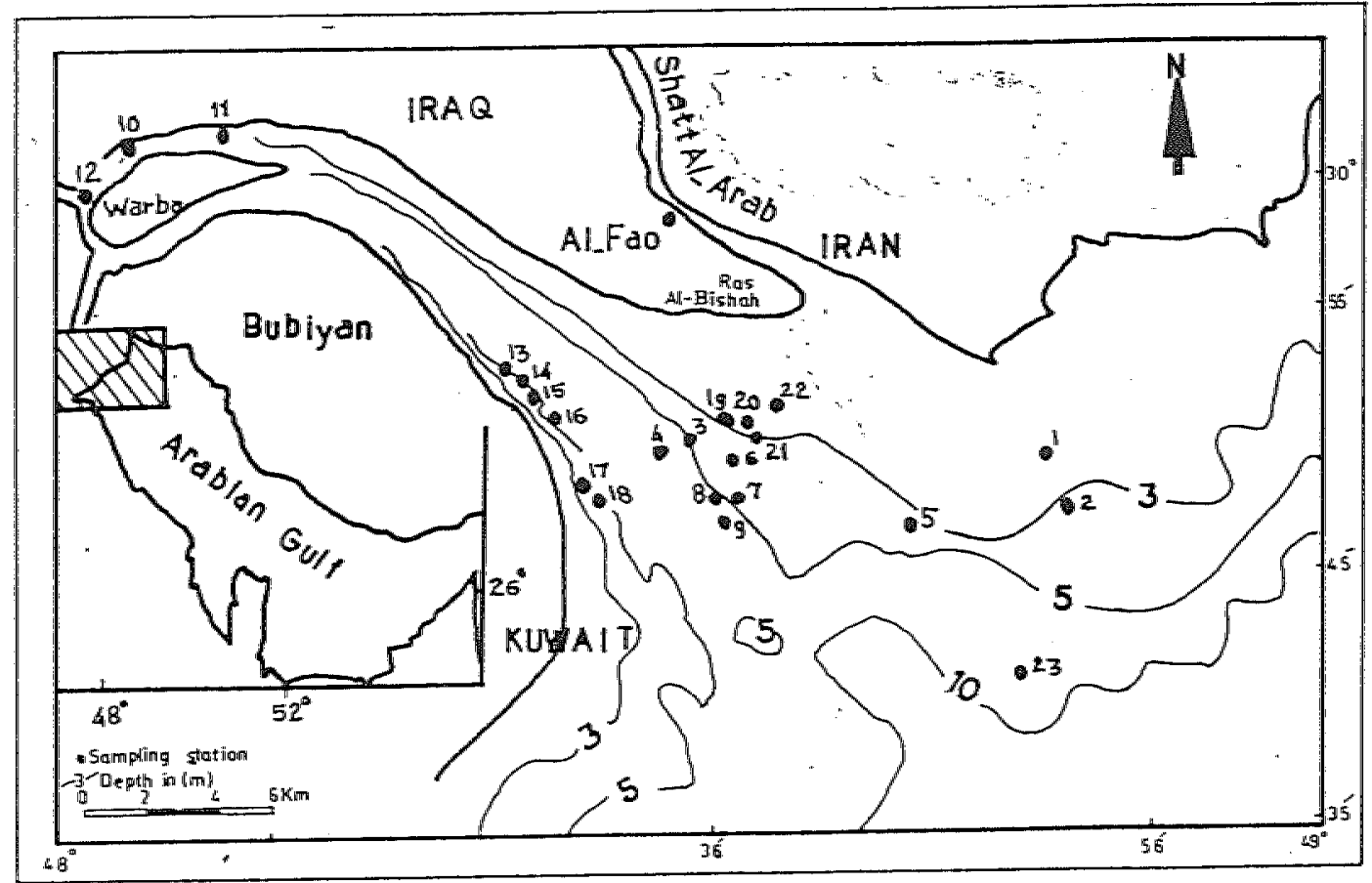

Fig. 1: Location map

According to more and Morel - Laurens (1983), Organisms play an important and dominant role in controlling trace metal chemistry in the ocean. They may increase trace metal solubilities by releasing complexing agents in the medium or on the contrary they may enhance the incorporation of metals into particles and then faster metal sedimentation in aquatic systems.

It is well known that marine sediments undergo various diagenetic modification and parts of marine organisms usually show low degree of such modification. Therefore, the current study attempts to offer a review of the mineralogy and the abundance of major, minor and trace elements besides the factors controlling their enrichment in the skeletal elements of Arabian Gulf invertebrate organisms.

\section{MATERIAL AND METHODS}

The sample of the marine bottom sediments were collected from 29 localities distributed in the modern sediments of NW Arabian Gulf, Iraq. The collection was carried out using Van Veen grab on Al-Fao research ship. Various types of faunal biogenic components were separated from each sample. The mineral compositions of 
shell components were determined using the X-Ray diffraction technique (Phillips PW 1060100 diffracto meter) under the following conditions:

Radiation: CuKa, voltage $=35 \mathrm{kv}$, current $=20 \mathrm{MA}$, filter $=\mathrm{Ni}$, Scan speed $=1^{\circ} / \mathrm{min}$, slit $=1-0.1-1$, scanning range: from $2^{\circ}$ to $34^{\circ} 2 \theta$ degrees.

The $\mathrm{SiO}_{2}, \mathrm{TiO}_{2}, \mathrm{Al}_{2} \mathrm{O}_{3}, \mathrm{FeO}, \mathrm{MnO}, \mathrm{MgO}, \mathrm{CaO}, \mathrm{K}_{2} \mathrm{O}, \mathrm{P}_{2} \mathrm{O}_{5}, \mathrm{CuO}, \mathrm{PbO}$ and $\mathrm{SrO}$. Contents were determined for several skeletal fragments using Electron Microprobe analyses technique (Geol. Surv. Finland. Espoo), Standards used were:

Wollastonite: $\mathrm{SiO}_{2}$, periclase : $\mathrm{MgO}$, Celestite : $\mathrm{SrO}, \mathrm{SO}_{3}$, Oligoclase : $\mathrm{Na}_{2} \mathrm{O}$, $\mathrm{Al}_{2} \mathrm{O}_{3}$, Biotite; $\mathrm{FeO}, \mathrm{TiO}_{2}, \mathrm{~K}_{2} \mathrm{O}$, Mn - Tentalite; $\mathrm{MnO}$, Pentlandite; NiO, Chalcopyrite; CuO Galena: $\mathrm{PbO}$, Apatite: $\mathrm{P}_{2} \mathrm{O}_{5}$.

The study area occupies the north western edge of the mesopotamian shallow shelf. The region has an arid, subtropical climate. The textural character of the sediments is mainly fine mud, followed by fine sands and Oolitic-pelletal carbonate bioclasts. Detailed studies are reported in separate paper by Darmoian and Lindquist (1988).

During 1976-1990 an intensive program concerning the Geology and Fisheries of the NW Arabian Gulf were carried out by Marine Science Centre, University of Basrah. This paper deals with the mineralogical and chemical properties of organic skeletal materials in the collected modern sediments. Samples provided for analysis were taken at the stations in Figure (1). The benthonic faunal individuals, found in the muddy and silty sediments as well as in the protected rocky and sandy environments, mostly composed of calcium carbonate secreting individuals. Darmoian and Lindquist (1988) reported the following skeletal materials; forams, ostracods, both micro and macro mollusk (including gastropods, bivalves (Scaphopoda), echinoderms spines and plates, sponge spicules, barnacles, crab fragments and polychaetae, (see also Karim and Salman 1988, Darmoian and Al-Rubaee 1988 and Al-Khuzaee 1988.

Skeleton chemistry has been used to solve many marine and oceanographic problems such as diagenesis of carbonate sediments, mechanism of dolomitization, age determination ..... etc.

Gunatlika (1975) found that the mineralogy of certain skeletons play an essential role in the distribution of $\mathrm{Mg}$ and $\mathrm{Sr}$.

Al-Aasm and Veizer (1982) through the study of cretaceous Rudist trace elements, showed a similarity in chemical composition between cretaceous and Holocene sea as. Al-Khuzaee (1998), on the other hand, reported the possibility of using certain dominant species of foraminifera as indicator of industrial pollution's problems.

The precision of chemical analysis were checked following the method of Rose et al. (1979), Maxwell (1968) and Stanton (1966) which are within the acceptable value, and the applied method were at high analytical accuracy (1-2\%).

\section{Mineralogy}

The X-Ray diffractograms (Fig. $2 \& 3$ ) revealed that Low-Mg calcite (LMC), High - Mg calcite and Aragonite represent the dominant minerals whereas, quartz, feldspar and dolomite represent the trace mineral in the shells under study. Biogenic and terrigenous source were suggested for dominant and trace minerals, respectively. 

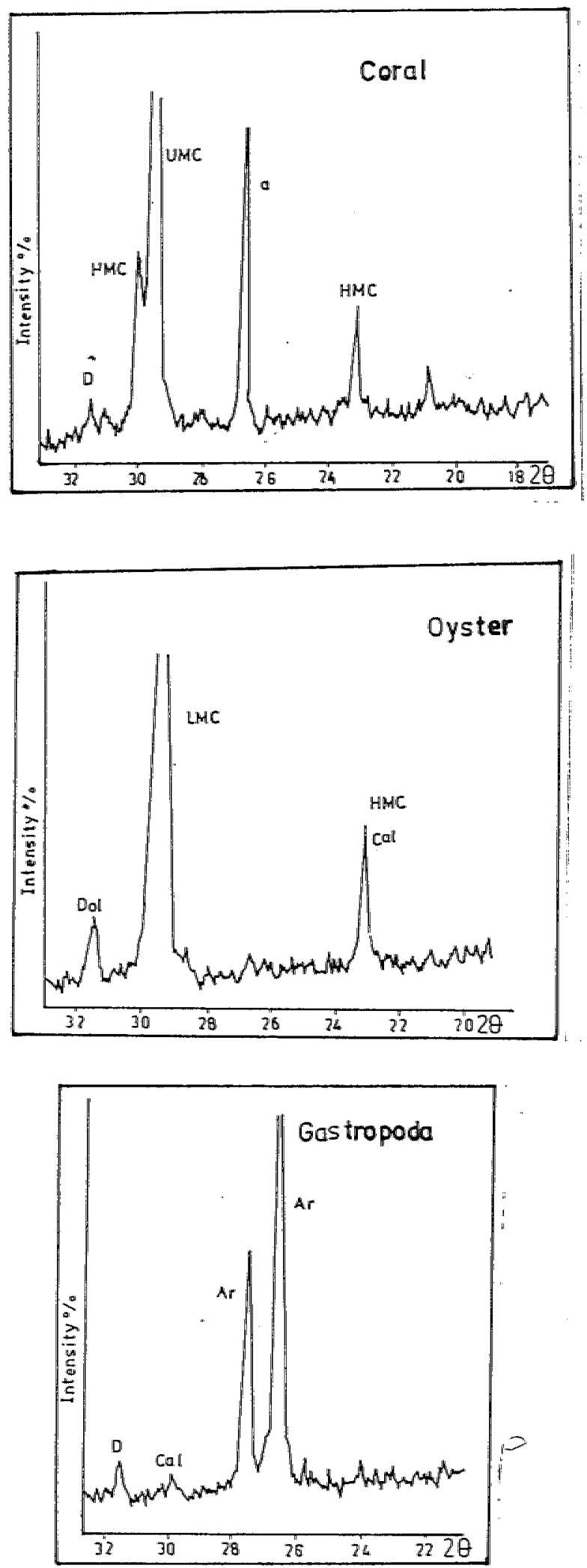

Fig. 2: X-ray diffractograms showing the main detected minerals in the shells of some organism of northwestern part of Arabian Gulf 

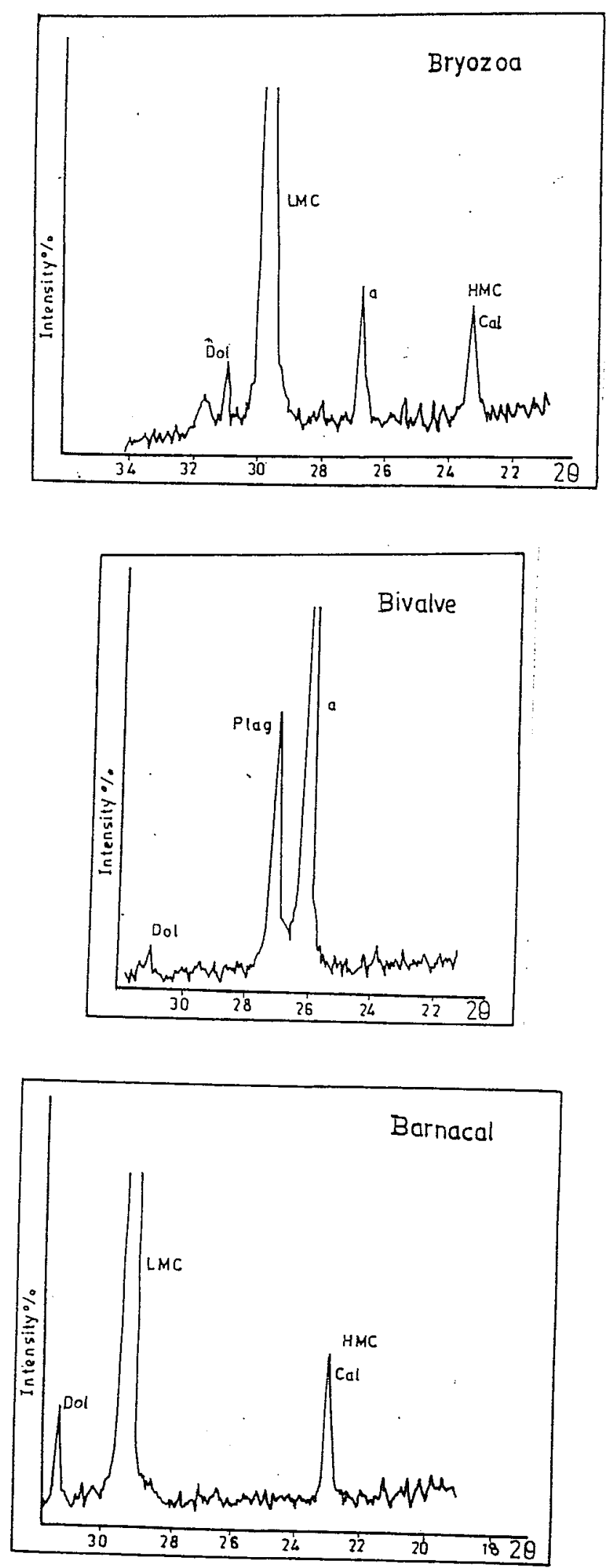

Fig. 3: X-ray diffractograms showing the main detected minerals in the shells of some organism of northwestern part of Arabian Gulf 


\section{Geochemistry}

The result of chemical analysis shows that the studied skeletal materials are of high $\mathrm{CaCO}_{3}$ contents. $\mathrm{CaO}$ and $\mathrm{CO}_{2}$ make up more than $90 \%$ of the chemical constituents.

The average concentration of $\mathrm{Ca}$ and $\mathrm{Si}$ in sea water are $4.1 \times 10^{5}$ and $3 \times 10^{3}$ $\mathrm{ppb}$, respectively (Faure, 1998). These two elements involved in biological cycle, therefore, their concentrations fluctuated from place to place and with depth of ocean basin (Mason and Moore, 1982). Large part of dissolved Ca and Si were abstracted from seawater to build shell tests. This is suggested by Al-Imarah and Jawad. (1994), who reported low concentration of $\mathrm{Ca}$ and $\mathrm{Si}$ in Arabian Gulf water relative to normal sea water. Most of silica occurred in the form of quartz as detected by XRD. While Ca is distributed in more than one phase; Low-Mg calcite, High-Mg calcite and Aragonite.

The analysed skeletal material showed minor amounts of $\mathrm{TiO}_{2}, \mathrm{FeO}$ and $\mathrm{Al}_{2} \mathrm{O}_{3}$ (Table 1). $\mathrm{TiO}_{2}$ and $\mathrm{FeO}$ could be related to the presence of anatase disseminated as lithogenous materials. These materials make the fillings of the pore space scavenged by marine organism (Collier and Edmond, 1983).

Most $\mathrm{Mg}$ is associated with carbonate minerals; Low-Mg calcite and High - $\mathrm{Mg}$ calcite rather than aragonite. Minor part of $\mathrm{Mg}$ possibly occurs as $\mathrm{Mg}(\mathrm{OH})_{2}$ (brucite) minerals (Schmitz, 1965 in Dodd, 1967).

Phosphorus represent members of nutrient elements, and it's distribution is affected by organism. The $P$ concentration in sea water increases with depth; most of $P$ abstracted from seawater and incorporated in non-skeletal part (soft tissuse), then recycled, after death and decomposition of these organism. The present $\mathbb{P}$ possibly occurs in the form of biogenic apatite.

Sodium and potassium represent the main alkaline elements incorporated in skeletal material under study. These two elements constituent the major cation in many surface and subsurface waters. Hence, their concentrations in shells of NW Arabian Gulf organisms related mainly to their aqueous concentrations. In general, the value of $\mathrm{K}$ is very low in comparison with $\mathrm{Na}$. This is believed to be due to firstly original low $\mathbb{K}$ concentration in sea water (Faure, 1998), and secondly, the low coprecipitation of $\mathrm{K}$ as the aqueous $\mathrm{Na}$ increases (White, 1977).

The average concentration of $\mathrm{Sr}$ in most of the skeletons under study is higher than that reported in sea water $(8 \mathrm{ppm})$, Table $(1)$. This result could be attributed to the mineralogical composition of the studied skeletons which consist mainlly of calcite and subordinate aragonite.

These two minerals are suitable to accommodate $\mathrm{Sr}$ and $\mathrm{Mg}$ in solid solution as $\mathrm{Sr} \mathrm{CO}_{3}$ and $\mathrm{Mg} \mathrm{CO}$, beside many trace elements such as $\mathrm{Na}, \mathrm{Mn}$ and Fe. In general aragonite contains more $\mathrm{Sr}$ than calcite. Sr occurs mainly in the form of $\mathrm{SrSO}_{4}$ (Celcetite) in aragonite and $\mathrm{SrCO}_{3}$ (Strontinite) in calcite (Al-Aasm and Veizer, 1986). This fact possibly eluciclate the occurrence of low amount of $\mathrm{SO}_{3}$ in the studied skeletons. Owing to Nelson, 1963 in Dodd (1967), the variation in $\mathrm{Mg}$ and Sr contents in the skeleton of the organisms of the Arabian Gulf may be related to their growth rates, the faster the growth rate, the lower the Sr contents. $\mathrm{Mg}$ varies with the growth rate in a somewhat different pattern than does Sr. 


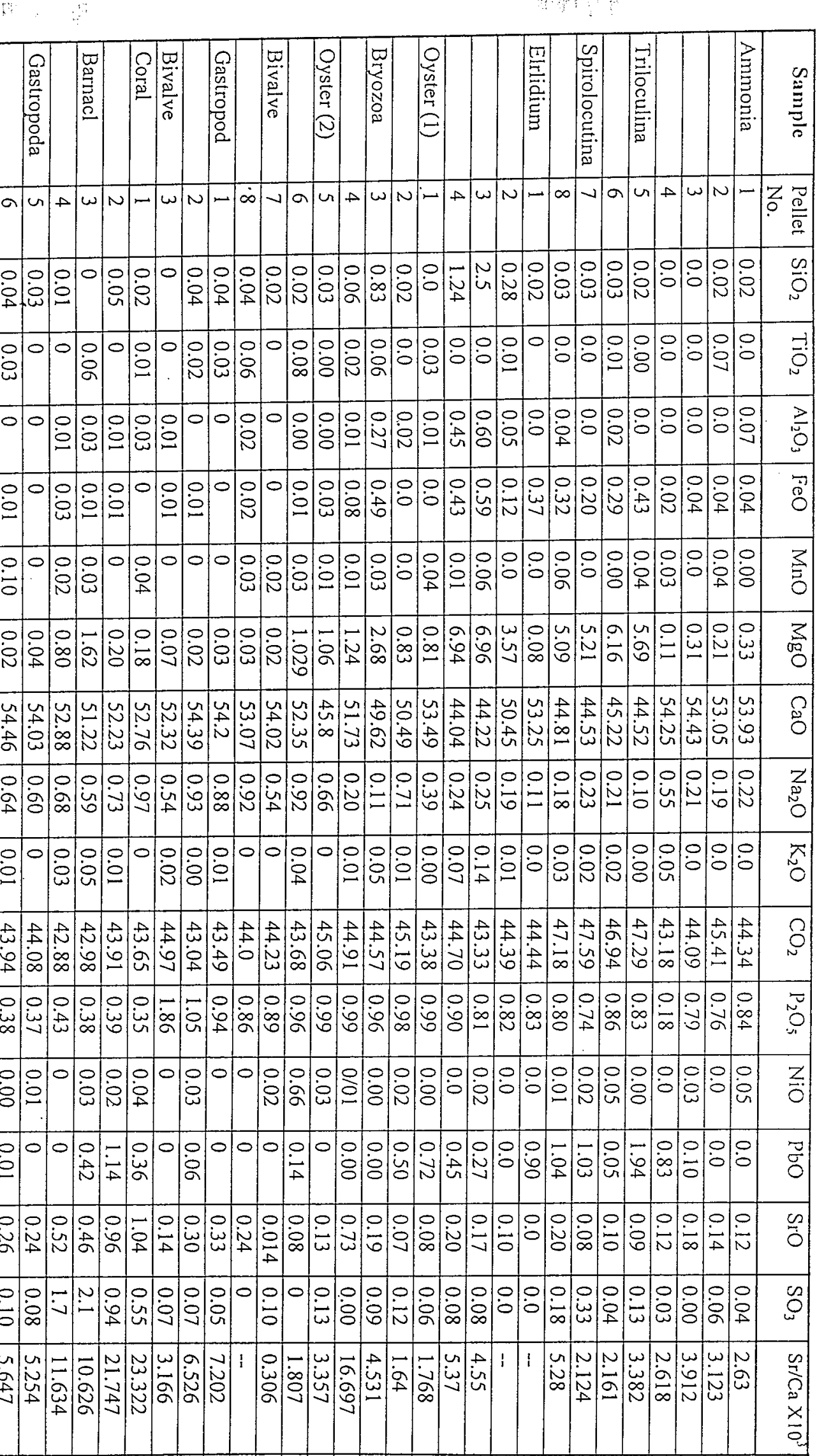

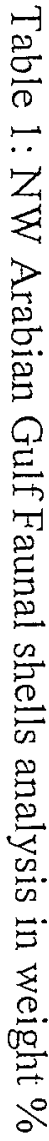


High fluctuations in $\mathrm{Pb}$ content were recorded in the skeletons, Triloculina and coral exhibit high concentration of this element (Table, 1) i.e hypoaccumulator organism. Therefore, it could be used as marine environmental pollution indicator for $\mathrm{Pb}$ Side-bySide with the sediments, it is apparent here, that most of $\mathrm{pb}$ is derived from urban area surrounding Arabian Gulf.

The sea water contents of $\mathrm{Mn}$ is completely dependent on atmospheric and river fluxes (Mason and Moore, 1982). Moreover, Ni is mainly associated with hydrocarbons (accident oil - spill), organic matter from industrial effluent, and from decomposition of marine organisms debris (Al-Khalaf et al., 1982). In general, $\mathrm{Mn}$ and Ni, discharged as river budget, usually associated with $\mathrm{Fe}$ - Oxide and nickelferrous silicate (Faure, 1998). Most of the present $\mathrm{Mn}$ and Ni possibly associated with biogenic carbonate mineral. According to Al-Aasm and Veizer (1986) $\mathrm{Mn}$ is largely enriched in diagenetic Low $\mathrm{Mg}$ Calcite (LMC) during transition of aragonite to LMC.

\section{Foraminifera}

Four groups are represented in the present study comprising main known genera; Triloculina, Spiroloculina, Ammonia and Elphidium, plate (1). The mineralogical analysis of skeletal material revealed that. Triloculina and Spiroloculina composed of High-Mg calcite, while Ammonia and Elphidium are of Low - Mg calcite. The high Sr contents in Triloculina shells reflect the high aragonite portion of shell because the larger $\mathrm{Sr}$ ion $(1.12 \mathrm{~A})$ would fit into the more open aragonite structure very readily. The high value of $\mathrm{SO}_{3}$ and $\mathrm{CO}_{2}$ together with $\mathrm{Sr}$ (Table), in Triloculina shells possibly reflects the presences of celestite and strontianite. According to Travis (1970) these two components are readily incorporated into calcite structure. On the other hand, spiroloculina shows high concentration of $\mathrm{PbO}$ (Table, 1), possibly as $\mathrm{PbCO}_{3}$ (Cerussite) due to high $\mathrm{CO}_{2}$ contents, Therefore, such shells could be used as indecation for the level of environmental pollution. Relatively low $\mathrm{Ca}$ values were reported in Triloculina and Spiroloculina skeletal material, this is related to the high $\mathrm{Mg}$ content possibly as high $\mathrm{MgCO}_{3}$ Substitution in calcite.

\section{Mollusca (Bivalves)}

Shell chemistry of bivalve showed that caicite is low in Mg as compared to most other groups. The Sr. concentration in bivalve calcite is the lowest of all invertebrates under study (Table, 1). Similar result were also documented by Dodd (1967). The latter author related the above results to the evolutionary trend in biochemistry of the calcification process through which foreign ions ( $\mathrm{Mg}$ and $\mathrm{Sr}$ ) were excluded from skeleton. Mineralogcally, the shells of bivalves consist mainly of LMC, while other shells (such as Gastropoda) consist predominatly of aragonite, Fig (1).

\section{Coral}

The mineralogical composition of coral in the study area exhibit that (LMC) is the dominant mineral in comparison whit that reported by Veizer et al. (1978) which is mainly consist of aragonite Fig (1). The available coral calcite shows very high $\mathrm{Sr}$ as compared to other invertebrates (Table 1). Consequently, the $\mathrm{Sr} / \mathrm{Ca}$ ratio is higher than in most other groups. Three factors appear to control Sr content in coral skeleton: water chemistry, mineralogical composition and physiology . 


\section{Bryozoa}

Detailed analyses of Bryozoa chemistry are lacking in the literature, because of their small size which makes separation procedures tedious. The Sr contents are very near to that present in Barnacles and greater than that of other in vertebrates organisms except Triloculina (Table, 2). The available bryzoan skeletons consist mainly of LMC Fig (3). The reported low Ca value may reflect a high content of organic matrix within the skeleton.

Table 2: Mineralogy \& $\mathrm{Ca}, \mathrm{Mg}$ and $\mathrm{Sr}$. contents in some type of fossils after flugel and Flugel - Kahler cited in Veizer et al., 1971 (A), and present work, (B).

\begin{tabular}{|c|c|c|c|c|c|}
\hline Type of fossils & Mineralogy & $\mathrm{Ca} \%$ & $\mathrm{Mg} \%$ & $\mathrm{Sr} \%$ & $\mathrm{Sr} / \mathrm{Ca} \times 10^{3}$ \\
\hline & & & A & & \\
\hline \multirow{2}{*}{ Algae } & \multirow{2}{*}{ Mg-Calcite } & 32 & 4.27 & 0.27 & 3.86 \\
\hline & & 32.6 & 4.03 & 0.31 & 4.35 \\
\hline Coral & Aragonite & 37.6 & - & 0.88 & 10.7 \\
\hline Echinoids & Mg-Calcite & -- & 2.7 & 0.15 & -- \\
\hline Miliolids & $\mathrm{Mg} \mathrm{CO}_{3}$ & 13.6 & -- & -- & -- \\
\hline \multicolumn{6}{|l|}{ Foraminifera } \\
\hline Benthonic & Mg-Calcite & 35.3 & 1.35 & 0.16 & 2.07 \\
\hline Planktonic & Mg-Calcite & -- & -- & -- & -- \\
\hline \multirow[t]{2}{*}{ Clobigerina } & Calcite & -- & 0.18 & 0.13 & $\ldots$ \\
\hline & & & $\mathrm{B}$ & & \\
\hline \multicolumn{6}{|l|}{ Foraminifera } \\
\hline Ammonia & $\begin{array}{l}\text { Low } \\
\text { Calcite }\end{array}$ & 38.529 & 0.25 & 0.118 & 3.073 \\
\hline Triloculina & $\begin{array}{ll}\text { High } & \mathrm{Mg}- \\
\text { Calcite }\end{array}$ & 31.575 & 5.93 & 0.803 & 25.441 \\
\hline Spiroloculina & $\begin{array}{l}\text { High } \\
\text { Calcite }\end{array}$ & 31.926 & 5.30 & 0.084 & 2.65 \\
\hline \multicolumn{6}{|l|}{ Mollusca } \\
\hline Bivalve, 1 & $\begin{array}{l}\text { Low Mg- } \\
\text { Calcite }\end{array}$ & 37.157 & 0.82 & 0.063 & 1.706 \\
\hline Bivalve, 2 & $\begin{array}{ll}\text { Low } & \mathrm{Mg}- \\
\text { Calcite } & \end{array}$ & 35.077 & 1.045 & 0.093 & 2.651 \\
\hline Castropoda, 1 & Aragonite & 38.808 & 0.03 & 0.211 & 5.441 \\
\hline Castropoda, 2 & Aragonite & 38.772 & 0.07 & 0.118 & 3.043 \\
\hline Coral & $\begin{array}{l}\text { Low Mg- } \\
\text { Calcite }\end{array}$ & 37.52 & 0.19 & 0.846 & 22.537 \\
\hline Barnacl & $\begin{array}{l}\text { Low } \mathrm{Mg}- \\
\text { Calcite }\end{array}$ & 37.2 & 1.21 & 0.414 & 11.137 \\
\hline Bryozoa & -- & 36.22 & 1.97 & 0.389 & 10.74 \\
\hline
\end{tabular}




\section{Barnacles}

The barnacle skeletons were once thought to be entirely calcite. But the XRD study of the present barnacle skeletons (Plate, 2) indicates a LMC with trace of aragonite Fig (3). The calcitic portion of barnacles is rather low in $\mathrm{Mg}$ while the same samples have the Sr content is higher than that of the other studied foram except coral (Table, 2 ).

\section{CONCLUSIONS}

The calcareous skeletons of the selected invertebrate fauna from the northwest Arabian Gulf consist mainly of Low-Mg calcite (Foraminifera, pelecypoela, Barnacles and coral), aragonite (Gastropoda), with traces of quartz, feldspar and dolomite.

The variation in the obtained chemical constituents among the studied skeletons are attributed to many factors such as the chemistry of sea water, skeleton mineralogy i.e aragonite contain higher concentration of $\mathrm{Sr}$ compared to low - Mg calcite, nature of chemical constituents, nutrient elements exhibit high concentration ( $\mathrm{Cu}, \mathrm{Si}, \mathbb{K}, \mathrm{P}$ ) in comparison with the rest of elements, orgamisms physiology, the faster the growth rate the lower $\mathrm{Sr}$ contents and biochemistry of the calcification process, through which $\mathrm{Mg}$ and $\mathrm{Sr}$ ions are excluded from some skeletons.

Triloculina and coral show high tendency to accumulate $\mathrm{Pb}$. Therefore they could be used to measure the level of pollution in the Arabian Gulf aquatic ecosystem.

\section{REFERENCES}

Al-Aasm, I.S. and Veizer, J., 1982. Chemical stabilization of low-Mg calcite an example of brachiopods: Jour. Sed. Pet, Vol. 52, pp. 1101-1109.

Al-Aasm, I.S. and Veizer, J., 1986. Diagentic stabilization of Aragonitc and low-Mg calcite -1 : Trace Elements in Rudists, Jour. Sed. Pet, Vol. 54, No. 1, pp.

Al-Imarah, F.J. M. and Jawad, A.H.M., 1994. Physico - chemical parameters of southern Iraqi water, North West Arabian Gulf, Marina Mesopotamica, Vol. 9, No. 1, pp. 1-12.

Al-Khzaee, R.A., 1998. Spreading of living and Fossil Foraminifera as an indicator of pollution, North West of the Arabian Gulf, Unpubl. MSC. Thesis, Basrah University, 93 p. (in arabic).

Collier, R.W., and Edmond, J.M. 1983. Plankton composition and Trace element Fluxes from the surface Ocean, in wong, C.S, Boyle, E., Bruland, K.W., Burton, J.D. and Goldberg. E.D. (eds). Trace Metals in sea water, plenum press, New York. 920 p.

Darmoian, S.A., and Lindqvist, K., 1988. Sediment in the Estuarine Environment of the Tigris/Euphrates Delta; Iraq: Arabian Geol. Jour., Vol. 23, pp 15-37.

Darmoian, S.A., and Al-Rubaee, K., 1988. Estuarine Benthonic Forminifera from Iraq. The Arabian Gulf. Jour. Geol. Soc. Iraq. Vol. 22, No 2, pp 56-76.

Dodd, J.R., 1967. Magnesium and Strontium in Calcareous skeletons. A review, Jour. Pal., Vol. 41, No. 6. Pp 1313-1328.

Faure, G., 1998, Principles and Applications of Geochemistry, 2 nd ed., Prentice Hall, New Jersy, $600 \mathrm{p}$.

Gunatliaka, A., 1975. The chemical composition of carbonate secreting Marine Organism from connemara, preccding of the Royal Irish Academy, Vol. 75, Section B, Number 27, pp , 543-556. 
Hartman, M., Lange, H., Seibold. E., and Walger, E., 1971. Oberflachen Sediment in persischen Golg und Golf von Oman, I, Reine C,4,p1-76.

Karim, H.H., and Salman, H.H., 1988, Geology of the Arabian Gulf, Bastah University Press, 329 p. (in arabic).

Khalaf, F., Literathy, P., and Anderlina, V., 1982. Vanadium as a tracer of oil pollution in the sediment of Kuwait, Hydrobiologia, Vol. 91, pp 147-154.

Mason, B., and Moore, C., 1982, Principles of Geochemistry, John Wiley and Sons, NewYork, 344 p.

Maxwell, J.A., 1968. Rock and mineral analysis Jhon wiley and Sons, NewYork 584p.

Morel, F.M.M., and Morel - Laurens, N.M.L., 1983. Trace metals and plankton in the Ocean; Fact and Speculations in "Trace Metals in sea water" wong, C.S., Boyle, E., Burland, K.W., Burton, J.D., and Goldberg, E.D. (eds), Plenum press, NewYork, $920 \mathrm{p}$.

Rose, A.W., Hawkes, H.E. and Webb, J.S., 1979. Geochemistry in Mineral Exploration, 2 nd ed. Academic press, London. 657 p.

Stanton, R.E., 1966. Rapid Method of trace element analysis for geochemical Application. Edward Annold (Publ.) Lims, 96 p.

Travis, D.F., 1970. The comparative Ultrastructure and organisation of five calcification (Ed.) H. Schracr, Amesterdam. North Holland Publishing Co., pp 203-212.

Veizer, J., Lemieux, J., Jones, B., Gibbling, M.R., and Savelle, J., 1971. Paleosalinity and dolomitization of a lower paleozoic carbonate sequence, Somerest and Prince of wales Island, Arctic Canada: Can. Jour. Earth Sci., Vol. 15 pp.1448-1461.

White, A.F., 1977. Sodium and Potassium Co-Preecipitation in Aragonite, Geochim. Cosomochim. Acta, Vol. 41, pp. 613-625. 


\section{Plate - I}

1.Quinqeloculina sp. x 180

2. Triloculina sp. $x 180$

3.Eliphidium sp. $x 180$

4. Spiroloculina sp. $x 100$

5.Gastropoda (cerlthium) $\times 60$

6. Gastropoda (epitonium) $\times 60$

7. Gastropoda (tupbo) $\times 60$

8.Pelecypoda (cyclymeris) $\times 30$

9.Pelecypoda (corbula) x 30

10.Bryozoa (three pieces) $\times 100$

\section{Plate - II}

Selected photographs; A-Solitary corals from shallow subtidal rock bottom. B-small barnacles, Balanus sp., found attached to intertidal rocks. 
Plate - I

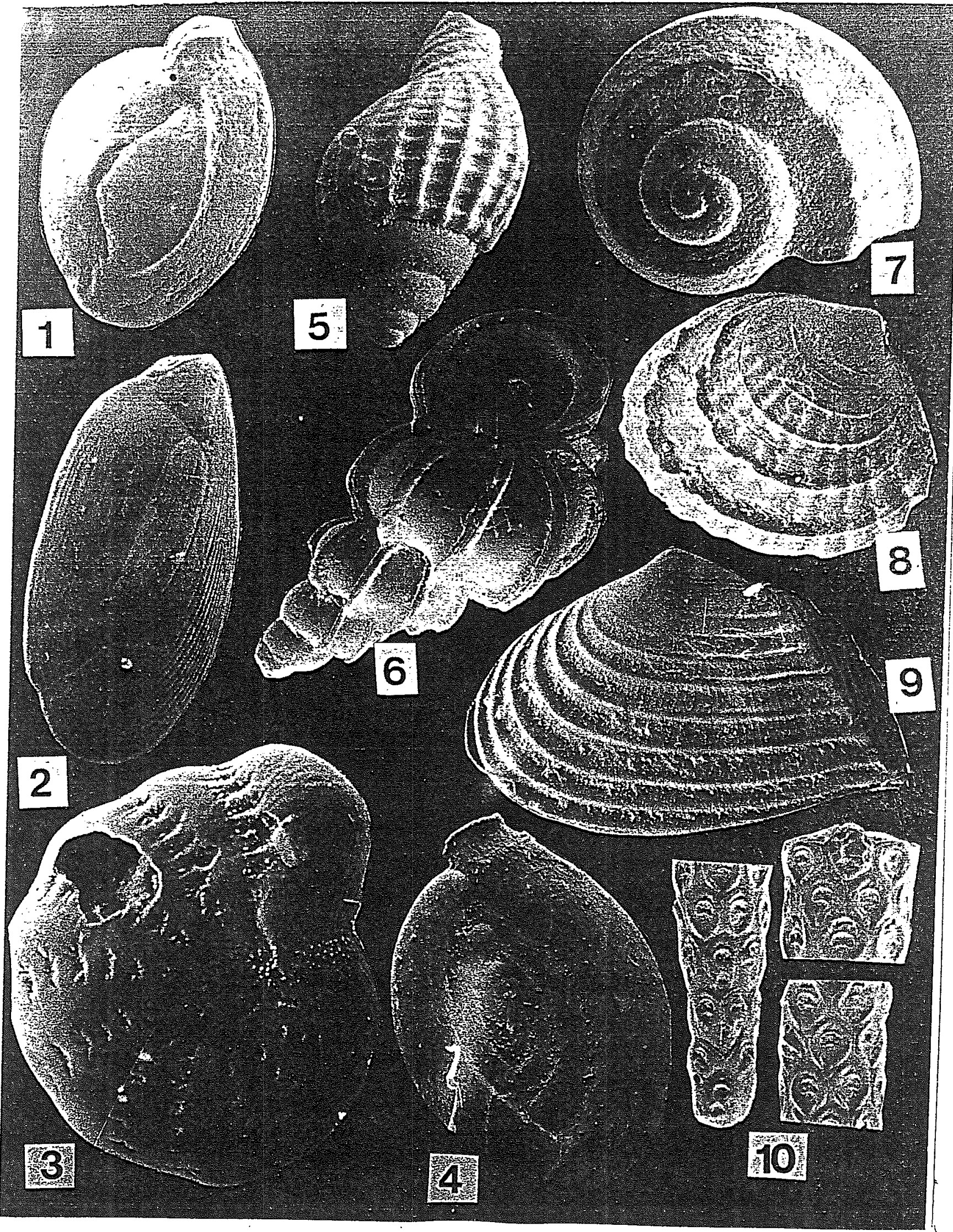




\section{Plate - II}

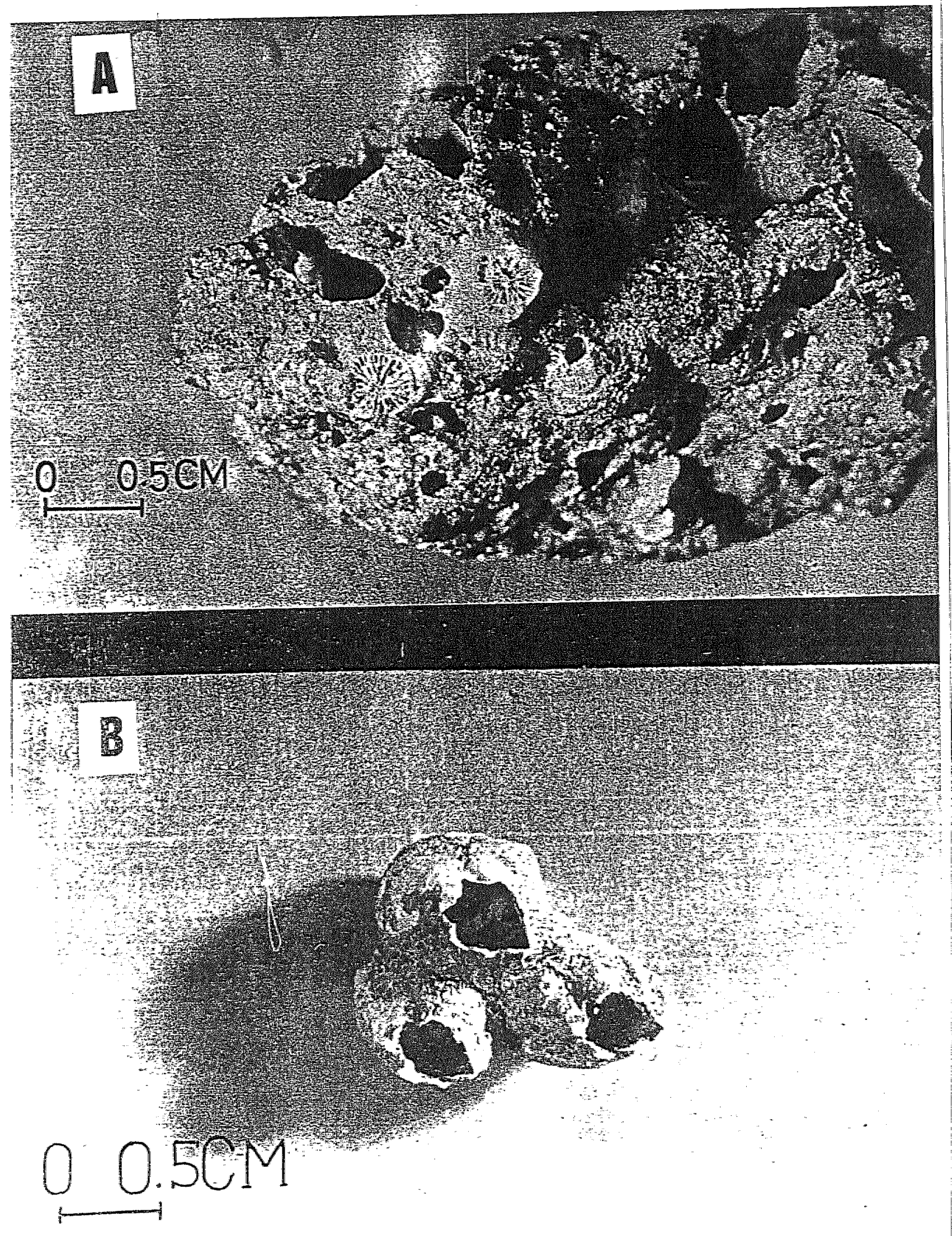

